Timeline

\title{
Timeline: Nursing's response to key COVID-19 events in Aotearoa New Zealand
}

Caz Hales ${ }^{1,2}$, PhD, RN, Senior Lecturer, School of Nursing, Midwifery

\& Health Practice; Operations Lead, COVID-19 Directorate

${ }^{1}$ Te Herenga Waka, Victoria University of Wellington, Wellington, Aotearoa New Zealand

${ }^{2}$ Manatü Hauora, Ministry of Health, Aotearoa New Zealand

${ }^{1}$ Corresponding Author: caz.hales@vuw.ac.nz

\section{Citation}

Hales, C. (2021). Timeline: Nursing's response to key COVID-19 events in Aotearoa New Zealand. Nursing Praxis in Aotearoa New Zealand, 37(3), 1-5.

https://doi.org.10.36951/27034542.2021.042

\section{Timeline table}

The purpose of the table is to provide a timeline summary of key COVID-19 events in Aotearoa New Zealand and the response of the nursing profession to keep the community safe, care for those with COVID-19, support the nursing workforce, and adapt and support nursing students to complete their qualifications. The timeline specifically records Aotearoa New Zealand's COVID-19 response between February 2020 and December 2021 when the "elimination" strategy implemented by the New Zealand Government (New Zealand Government, 2020) guided Ministry of Health directives and nursing practices. The key events have been mapped out using the New Zealand Government (2021) and Ministry of Health (2021a) official sources, namely their two COVID19 websites. This Special Issue of Nursing Praxis in Aotearoa New Zealand provides evidence of nursing's response to the pandemic. Articles are cited in the table in reference to events on the timeline.

\begin{tabular}{|c|c|c|}
\hline Date & Key Events & Summary of nursing response \\
\hline 31 December 2019 & Cluster of cases in Wuhan, China & Global pandemic declared \\
\hline 13 January 2020 & First case of COVID-19 outside China & \multirow{4}{*}{$\begin{array}{l}\text { Nurses lead the establishment of the National Close } \\
\text { Contact Service (Hales et al., 2021). } \\
\text { Infection control nurse leaders develop an integrated } \\
\text { infection control and prevention strategy (Berger, } \\
\text { 2021). } \\
\text { Nurses prepare services for infected patients: } \\
\text { Emergency Departments redesign triage practices } \\
\text { (Lockett, 2021); ward staff trained in non-invasive } \\
\text { ventilation (Malik, 2021). }\end{array}$} \\
\hline 3 February 2020 & $\begin{array}{l}\text { Ban on the entry of overseas } \\
\text { travellers from or transiting through } \\
\text { China }\end{array}$ & \\
\hline 28 February 2020 & $\begin{array}{l}\text { First reported case in Aotearoa New } \\
\text { Zealand }\end{array}$ & \\
\hline 5 March 2020 & The first community transmission & \\
\hline 11 March 2020 & $\begin{array}{l}\text { World Health Organization declared } \\
\text { global pandemic }\end{array}$ & \multirow{4}{*}{$\begin{array}{l}\text { Aged Residential Care's newly formed Nursing } \\
\text { Leadership Group prepare to protect their vulnerable } \\
\text { older adult population (Hughes et al., 2021). }\end{array}$} \\
\hline 19 March 2020 & $\begin{array}{l}\text { Borders close; New Zealanders } \\
\text { returning home to self-isolate } 14 \\
\text { days }\end{array}$ & \\
\hline 17 March 2020 & $\begin{array}{l}\text { Government announces } \$ 500 \text { million } \\
\text { for health services to combat the } \\
\text { Disease }\end{array}$ & \\
\hline 21 March 2020 & $\begin{array}{l}\text { Government release } 4 \text { level Alert } \\
\text { level framework; Country at Alert } \\
\text { Level } 2\end{array}$ & \\
\hline
\end{tabular}




\begin{tabular}{|ll}
\hline 23 March 2020 & Country enters Level 3 \\
\hline 25 March 2020 & $\begin{array}{l}\text { Country enters Level 4 (Full national } \\
\text { lockdown) }\end{array}$ \\
\hline
\end{tabular}

\begin{tabular}{ll}
\hline 29 March 2020 & First death \\
\hline 9 April 2020 & $\begin{array}{l}\text { Managed Isolation and Quarantine } \\
\text { facilities (MIQF) operational; All } \\
\text { returnees to isolate for 14 days in } \\
\text { MIQF }\end{array}$
\end{tabular}

27 April $2020 \quad$ Country returns to Level 3

\begin{tabular}{ll}
\hline $\mathbf{1 3}$ May 2020 & Country returns to Level 2 \\
\hline $\mathbf{1}$ June 2020 & Country returns to Level 1
\end{tabular}

1 June $2020 \quad$ Country returns to Level 1

\section{First community outbreak}

6,228 nurses without Annual Practising Certificates contacted by Nursing Council of New Zealand to aid COVID-19 response (NCNZ, 2020a).

Nurses seconded to COVID-19 response roles: MIQFs, testing centres and community support.

Māori nurse leaders support Māori workforce and communities (Davis et al., 2021).

Nursing students withdrawn from clinical placements and all education moves to online learning (Thompson et al., 2021).

Nurses engage in information and communication technologies to provide care (Collins \& Honey, 2021)

Academic nurse educators provide frontline clinical support (Blunden \& Poulsen, 2021).

Nurse educators provide additional pastoral care to nursing students (Winnington \& Cook, 2021).

\section{August 2020}

Community transmission: Auckland enters Level 3; Rest of the country enters Level 2

\begin{tabular}{ll}
\hline 21 September & $\begin{array}{l}\text { Except for Auckland, rest of the } \\
\text { 2020 }\end{array}$ \\
\end{tabular}

8 October $2020 \quad$ Auckland returns to Level 1

\section{November 2020 Last reported community case}

19 November 2020 Mask mandatory on public transport in Auckland; Masks mandatory for all flights

\section{Second community outbreak}

Nurses working in MIQF feel the pressures of protecting Aotearoa New Zealand borders (Jamieson et al., 2021).

Frontline nurses' wellbeing under the pressures of working during the pandemic examined (Cook et al., 2021).

Nursing students start to return to clinical placements. Tertiary education providers plan for dual mode delivery of nursing programmes. Nursing Council of New Zealand announce two additional State Final Examination opportunities (NCNZ, 2020b).

Nursing Council of New Zealand issued over 1000 interim Annual Practising Certificates to support COVID19 nursing roles (NCNZ, 2020b)

\section{February 2021 Community transmission: Auckland enters Level 3; Rest of the country \\ Third community outbreak \& Vaccination programme commences} enters 2

\begin{tabular}{|ll}
\hline 18 February 2021 & $\begin{array}{l}\text { Auckland returns to Level 2; Rest of } \\
\text { the country returns to Level 1 }\end{array}$ \\
\hline 19 February 2021 & $\begin{array}{l}\text { First vaccination against COVID-19 } \\
\text { (Pfizer-BionTech vaccine Comirnaty) } \\
\text { Vaccinators first recipients of the } \\
\text { vaccine }\end{array}$
\end{tabular}

20 February $2021 \quad \begin{aligned} & \text { Vaccination of border workers } \\ & \text { commence }\end{aligned}$

23 February 2021 Auckland returns to Level 1

28 February 2021 Auckland returns to level 3; Rest of the country to Level 2

Nurses train as COVID-19 vaccinators. Nationwide vaccination programme commences with border and healthcare workers (Ministry of Health, 2021b).

Vaccination centres set up around the country.

Māori nurses lead the vaccination drive in rural and urban communities providing cultural and clinical reassurance (Clark et al., 2021).

Tertiary nursing education providers continue to offer dual delivery mode education programmes for the 2021 academic year. 


\section{March $2021 \quad$ Auckland returns to Level 2; Rest of} the country to Level 1

\begin{tabular}{ll}
\hline 12 March 2021 & Auckland returns to Level 1 \\
\hline 22 March 2021 & Border worker case \\
\hline 8 April 2021 & Border worker case \\
\hline 11 April 2021 & Border worker case \\
\hline 19 April 2021 & $\begin{array}{l}\text { Trans-Tasman quarantine free travel } \\
\text { commences }\end{array}$ \\
\hline
\end{tabular}

\begin{tabular}{ll}
\hline 20 April 2021 & Border worker case \\
\hline 24 April 2021 & $\begin{array}{l}\text { Quarantine free travel suspended } \\
\text { between different Australian States } \\
\text { and Aotearoa New Zealand over the } \\
\text { following month }\end{array}$ \\
\hline
\end{tabular}

23 June $2021 \quad$ Wellington enters Level 2 for 3 days. Quarantine free traveller with COVID visits Wellington

12 July $2021 \quad \begin{aligned} & \text { Mandatory vaccinations for border } \\ & \text { worker }\end{aligned}$

30 July $2021 \quad$ Health care worker quarantined due to minor PPE breach

\section{August 2021 Community transmission: Country} moves to Level 4

$\begin{array}{ll}20 \text { August 2021 } & \begin{array}{l}\text { People aged 12-15 now eligible for } \\ \text { vaccination with Pfizer-BioNTech } \\ \text { COVID-19 vaccine }\end{array}\end{array}$

31 August 2021 Auckland and Northland remain at Level 4; Rest of the country returns to Level 3

7 September 2021 Auckland remains at Level 4; Rest of the country moves to Level 2 Delta

$\begin{array}{ll}\text { 16 September } & \text { Government announces vaccination } \\ \mathbf{2 0 2 1} & \text { rate target of } 90 \%\end{array}$

\begin{tabular}{ll}
\hline October 2021 & Hard border instigated around \\
& $\begin{array}{l}\text { Auckland, Police Road checks in } \\
\text { place }\end{array}$
\end{tabular}

17 November 2021 'My Vaccine pass' launched - official proof of full vaccination status

26 November 2021 Omicron named a variant of concern by the World Health Organization

\section{MIQF border-community transmission \& Quarantine Free Travel}

MIQF nurses encounter further stigmatisation following border worker COVID-19 cases (Jamieson et al., 2021).

Nursing Council of New Zealand publishes a guideline statement: COVID-19 vaccine and your professional responsibility (NCNZ, 2021a).

Nursing Council of New Zealand announces there is no place for antivaccination messages in professional nursing practice, including via social media (NCNZ, 2021b).

\section{Delta variant (fourth) community outbreak}

New Zealand Nurses Organisation cancels planned Strike Action for $19^{\text {th }}$ August considering the new community outbreak (NZNO, 2021).

Pacific communities are most affected by the Delta outbreak.

Pacific nurse leaders call for the strengthening of the pacific nursing workforce (Smith et al., 2021).

Mandatory COVID-19 Vaccination Order announced for nurses. Nurses must be fully vaccinated by 1 Dec 2021 (Hipkins, 2021, October 11).

Auckland nursing students given permission to sit State final examinations ahead of completing required clinical hours for the transition to practice placement (NCNZ, 2021c).

Nursing Council of New Zealand announce an extra state final examination date for students (NCNZ, 2021c).

Nursing Council of New Zealand publish guidance statement on providing care to patients not vaccinated against COVID-19 (NCNZ, 2021d) 


\section{December 2021 New Zealand moves to COVID-19 Protection framework; known as Traffic light system}

\section{Living with COVID}

Elimination strategy replaced. New era in COVID-19 nursing commences.

\author{
Global statistics (John Hopkins University, 2021) \\ Total cases: $265,388,145$ \\ COVID-19 deaths: 5,248,747
}

COVID-19 deaths: 44

Vaccine doses administered:

$7,724,694$
Hughes, F. A., Blackwell, A., Bish, T., Chalmers, C., Foulkes, K., Irvine, L., Robinson, G., Sherriff, R., \& Sisson, V. (2021). The coming of age: Aged residential care nursing in Aotearoa New Zealand in the times of COVID-19. Nursing Praxis in Aotearoa New Zealand, 37(3), 25-29.

https://doi.org.10.36951/27034542.2021.030

Jamieson, I., Andrew, C. \& King, J., (2021). Keeping our borders safe: The social stigma of nursing in managed isolation and quarantine border facilities during the COVID-19 pandemic. Nursing Praxis in Aotearoa New Zealand, 37(3), 53-61. https://doi.org.10.36951/27034542.2021.035

John Hopkins University. (2021). Coronavirus COVID-19 (2019-nCoV). Author. https://www.arcgis.com/apps/dashboards/bda7594 740fd40299423467b48e9ecf6

Lockett, J. (2021). Emergency Department pandemic preparedness: Putting research into action. Nursing Praxis in Aotearoa New Zealand, 37(3), 20-21. https://doi.org.10.36951/27034542.2021.028

Malik, Z. (2021). Reviving resuscitation skills: Noninvasive ventilator training for ward nurses. Nursing Praxis in Aotearoa New Zealand, 37(3), 22-24. https://doi.org.10.36951/27034542.2021.029

Ministry of Health. (2021a). COVID-19 (novel coronavirus). Author. https://www.health.govt.nz/ourwork/diseases-and-conditions/covid-19-novelcoronavirus

Ministry of Health. (2021b, February 19). COVID-19 vaccine's trial run. Author.

https://www.health.govt.nz/news-media/mediareleases/covid-19-vaccines-trial-run

New Zealand Government. (2020). National Action plan 3: National Crisis Management Centre. Version 3. Author. https://covid19.govt.nz/about-our-covid-19response/legislation-and-key-documents/

New Zealand Government. (2021). Unite against COVID19. Unite against COVID-19. Author. https://covid19.govt.nz/

New Zealand Nurses Organisation. (2021). Nurses withdraw strike action after lockdown declared. Author. https://www.nzno.org.nz/about us/media releases/a rtmid/4731/articleid/5315/nurses-withdraw-strikeaction-after-lockdown-declared

Nursing Council New Zealand (NCNZ). (2020a). Newsletter April 2020. Author. 
https://www.nursingcouncil.org.nz/Public/News Me dia/Publications/Newsletters/NCNZ/publicationssection/Newsletters.aspx?hkey=996bb739-ca09-4f949076-1f17bb14c395

Nursing Council New Zealand (NCNZ). (2020b).

Newsletter October 2020. Author.

https://www.nursingcouncil.org.nz/Public/News Me dia/Publications/Newsletters/NCNZ/publicationssection/Newsletters.aspx?hkey=996bb739-ca09-4f949076-1f17bb14c395

Nursing Council New Zealand (NCNZ). (2020c).

Newsletter December 2020. Author.

https://www.nursingcouncil.org.nz/Public/News Me dia/Publications/Newsletters/NCNZ/publicationssection/Newsletters.aspx?hkey=996bb739-ca09-4f949076-1f17bb14c395

Nursing Council New Zealand (NCNZ). (2021a). Guidance statement COVID-19 vaccine and your professional responsibility. Author.

https://www.nursingcouncil.org.nz/NCNZ/Newssection/newsitem/2021/5/Guidance statement COVID19 vaccine and your professional responsibility.aspx

Nursing Council New Zealand (NCNZ). (2021b). Guidance statement on providing care to patients not vaccinated against COVID-19. Author.

https://www.nursingcouncil.org.nz/NCNZ/Newssection/news-

item/2021/11/Guidance statement on providing car e to patients not vaccinated against COVID-19.aspx
Nursing Council New Zealand (NCNZ). (2021c). Newsletter July 2021. Author. https://www.nursingcouncil.org.nz/Public/News_Me dia/Publications/Newsletters/NCNZ/publicationssection/Newsletters.aspx?hkey=996bb739-ca09-4f949076-1f17bb14c395

Nursing Council New Zealand (NCNZ). (2021d). Newsletter October 2021. Author.

https://www.nursingcouncil.org.nz/Public/News Me dia/Publications/Newsletters/NCNZ/publicationssection/Newsletters.aspx?hkey=996bb739-ca09-4f949076-1f17bb14c395

Smith, A., Fereti, S., \& Adams, S. (2021). Inequities and perspectives from the COVID-Delta outbreak: The imperative for strengthening the Pacific nursing workforce in Aotearoa New Zealand. Nursing Praxis in Aotearoa New Zealand, 37(3), 94-103. https://doi.org.10.36951/27034542.2021.040

Thomson, P., Richardson, A., \& Foster, G. (2021). Collaborative learning in the COVID-19 pandemic: A change to the delivery of undergraduate nursing education. Nursing Praxis in Aotearoa New Zealand, 37(3), 34-36. https://doi.org.10.36951/27034542.2021.032

Winnington, R., \& Cook, C. (2021). The gendered role of pastoral care within tertiary education institutions. Nursing Praxis in Aotearoa New Zealand, 37(3), 37-40. https://doi.org.10.36951/27034542.2021.033

Funding: None

Conflicts of Interest: None 